\title{
Challenges of Islamic Supervisory in The Islamic Financial Technology Industry
}

\author{
Rifqi Muhammad \\ Universitas Islam Indonesia, Yogyakarta, Indonesia \\ email: rifqimuhammad@uii.ac.id \\ Rima Lanaula \\ Universitas Islam Indonesia, Yogyakarta, Indonesia \\ email: rimalanaula@gmail.com
}

\begin{abstract}
Islamic financial industry is increasingly developing with the presence of financial technology both in the form of peer to peer lending and crowdfunding. Islamic financial technology (fintech) enables sharia business players to formulate financing schemes using innovative and diverse sharia contracts. This has become a challenge in the aspect of sharia supervision due to limited regulations, corporate governance, and human resource capabilities. This paper will discuss the development of the financial technology industry in Indonesia and specifically the development of Islamic financial technology in terms of the growth in the number of service providers, the amount of financing, regulation and corporate governance. Secondly, this paper will discuss the challenges faced in the field of sharia compliance and the role of the sharia supervisory board in sharia supervision. Third, this paper will formulate corporate governance and human resource competencies of sharia supervisory board to encourage sharia compliance. Finally, this paper will formulate the conclusions and recommendations for improving regulation of the financial technology industry.
\end{abstract}

Keywords: Islamic fintech; shariah compliance; shariah supervisory board.

\begin{abstract}
Abstrak: Industri keuangan syariah semakin diramaikan dengan munculnya teknologi finansial (financial technology) baik yang berbentuk peer to peer lending maupun crowdfunding. Islamic financial technology (fintech) memungkinkan para pelaku bisnis syariah untuk merumuskan skema pembiayaan menggunakan akad-akad syariah yang semakin inovatif dan beragam. Hal ini menjadi tantangan dalam aspek pengawasan syariah karena keterbatasan regulasi, tata kelola perusahaan (corporate governance), dan kemampuan sumber daya manusia. Paper ini akan membahas perkembangan industri teknologi finansial di Indonesia dan secara khusus perkembangan Islamic financial technology dari sisi pertumbuhan jumlah penyedia jasa, jumlah pembiayaan, regulasi maupun tata kelola perusahaan. Kedua, paper ini membahas tantangan yang dihadapi dalam bidang kepatuhan syariah dan peran DPS (Dewan Pengawas Syariah) dalam pengawasan syariah. Ketiga, paper ini merumuskan tata kelola perusahaan dan kompetensi sumber daya
\end{abstract}

Economica: Jurnal Ekonomi Islam - Volume 10, Nomor 2 (2019) 
Rifqi Muhammad and Rima Lanaula

manusia DPS untuk mendorong kepatuhan syariah Islamic financial technology. Akhirnya, paper ini merumuskan kesimpulan dan rekomendasi untuk perbaikan regulasi industri teknologi finansial.

Kata Kunci: fintek syariah; kepatuhan syariah; Dewan Pengawas Syariah. 


\section{Introduction}

The practice of Islamic economics has developed very rapidly along with the development of public knowledge on the business and technological innovations that can change human lifestyles (Rusydiana, 2018). The practice of Islamic economics, which was initially only discussed in classrooms and scientific forums, has now become an economic power to contribute in the global economic competition. One sector that has very aggressive and innovative development is the Islamic financial sector. Especially with the 4.0 industrial revolution, the role of information technology has become increasingly strategic in the development of the Islamic financial industry. One evidence of this is the existence of financial technology (fintech) which change the map of financial industry competition. Financial technology based on sharia principles (Islamic fintech) is a new business that breaks through the boundaries of financial industry regulations and seals the relationship between investors and business players in the real sector.

Currently the Financial Services Authority (OJK) has issued POJK Number 77/POJK.01/2016 concerning the Implementation of Technology-Based Lending and Borrowing Services as a legal basis for operational activities for financial technology industry players, especially with the peer-to-peer lending scheme (Financial Services Authority, 2016). For November 2019, the data of OJK showed that the financing activities carried out by the financial technology industry nationally that were successfully recorded by the OJK amounted to IDR 74,544.70 billion (Financial Services Authority, 2019). In a very early age and limited regulatory infrastructure, this figure is considered quite large although this number also does not reflect the activities of the financial technology industry operating in Indonesia. Actually, there are still only a few actors who apply for business permits because of the less optimal of law enforcement.

Economica: Jurnal Ekonomi Islam - Volume 10, Nomor 2 (2019) 
This shows that the government as regulators seems too late to respond the very fast development of financial technology. Regulators have also not responded to the development of other types of financial technology, such as crowdfunding and Islamic fintech. Islamic fintech has inherent characteristics as a derivative of the Islamic financial industry that carries the mission of grounding sharia principles in its business activities. Not only offering sources of funding, Islamic fintech must participate in maintaining consistency in the implementation of business activities that are free of usury, maisyr, gharar, and falsehood elements.

If compared with the Islamic banking which is growing first, then the process of establishment of several Islamic fintech in Indonesia cannot be controlled because there is no regulation yet published by $0 \mathrm{JK}$, meanwhile the practice the practice is rife in cyberspace. When the first Islamic banks operated in Indonesia in 1991, continued by the establishment of Bank Syariah Mandiri (BSM) in 1999, there is no doubt that at the micro level also established Islamic microfinance institution such as BMT (Baitul Maal wa Tamwil) in the society. However, at that time the human resources already understood that the Islamic financial institution must maintain the sharia compliance process through a corporate governance mechanism by pointing the Sharia Supervisory Board (SSB) that has a role in controlling its sharia compliance implementation. It is different with Islamic fintech, which currently appears to leave the role of SSB with the reason that there is no regulation for them. Whereas Law Number 40 of 2007 concerning Limited Liability Companies has provided legal support regarding the existence of SSB in Article 109 which states that a limited liability company that carries out operations based on sharia principles, besides having a board of commissioners, must also have SSB. This is one of the main reasons for the importance of sharia supervision in the Islamic fintech industry.

Several previous studies on issues and challenges for SSB in Islamic financial institutions are the studies from Izzatika and Lubis (2016), Todorof 
(2018), Marzuki (2018), and Dz (2018). However, those studies only focus on general competence and no connecting them with the innovation of fintech. Therefore, this paper will focus on the challenges of sharia supervision in the Islamic fintech industry. In addition, this paper will also formulate corporate governance and the competence of SSB members to encourage the sharia compliance of Islamic financial technology.

\section{Literature review}

\section{Development of financial technology and its types}

Definition of financial technology, which is later referred to as fintech, is set in the regulation of the deputy members of Bank Indonesia No. 19/15/PADG/2017 on Procedures of Registration, Submission of Information and Monitoring of the Implementation of Financial Technology. Financial technology is the use of technology in the financial system that produces new products, services, technology and/or business models and have an impact on monetary stability, financial system stability and/or efficiency, smoothness, security and reliability of the payment system. Fintech can provide benefits for consumers or borrowers, investors, and banks (Marsudi and Widjaja 2019). However, on the other hand, it also has potential risks which, if not properly mitigated, could disrupt the financial system. Therefore, parties who are going to establish a business in the fintech sector must obtain a permit from the Financial Services Authority in accordance with OJK regulation Number 13/POJK.02/2018 concerning Digital Financial Innovation, especially for Fintech companies that provide financing using a peer to peer lending scheme. Meanwhile, fintech companies that have products in the form of e-money will be required to obtain a permit for Bank Indonesia activities in accordance with Bank Indonesia Regulation (PBI) Number 19/12/PBI/2017 concerning the Implementation of Financial Technology.

Islamic fintech is a technology-based business with innovative financial services or products using Islamic or sharia schemes (Rusydiana, 2018). 
Fintech has undergone several evolutionary processes and various types, but the most popular in Indonesia are crowdfunding and peer to peer (P2P) lending. Crowdfunding with the principles of sharia, began to appear in Singapore in the form of Ethics Pte which has been established since March 2014 (Rasyid, Setyowati, and Islamiyati, 2017).

Furthermore, this regulation also set the obligation to register for financial technology that carries out activities with the following criteria: (a) innovative; (b) having impact on the existing products, services, technology and/or financial business models, (c) providing benefits to the community; and (d) wider usage. Hadad (2017) explains that there are at least three stages of fintech evolution. The first fintech evolution (fintech 1.0) occurred in 18661987, which "merchants can order products over the phone and turn their wealth around the world without hard effort or even without problems". Then fintech 2.0 occurred in 1987-2008, through the automatic teller machine (ATM) is the most important financial innovation. Furthermore, fintech 3.0 3.5 has developed from 2008 to present, with the emergence of hundreds of start-ups offering various alternatives to traditional banking. The development of fintech globally (Australia, China, US, and UK) is classified as very fast and is expected to continue to develop until 2020 (Hadad, 2017). For Indonesia, based on data from the 0JK and the Indonesian Fintech Association, since 2006-2019, fintech has grown rapidly, especially in 2015 - 2019. Report from 0JK (2019) shows that there are 164 companies which have licensed and registered in OJK as fintech lending companies as of December 20, 2019.

In Indonesia, fintech can be classified into four types. The first type is called payment, clearing and settlement. This type of fintech provides payment system services that are still within the realm of Bank Indonesia, such as e-wallets or payment gateways. The second type is the market aggregator, which have functions to collect and process data on available financial products to help users in making decisions. This type of fintech compares various aspects such as price, features, and benefits of each financial 
product. The third type is risk management and investment. This type of fintech provides services to assess the financial condition of its users and perform financial planning only through smartphones. This type has a function like an advisor. Then, the fourth type is called crowdfunding and peer to peer (P2P) lending. Crowdfunding is a form of collective cooperation. People who have similar concern and trust are connected to each other and collect money together in support of businesses initiated by other people or an organization (Rasyid, Setyowati, and Islamiyati, 2017). The collection of money is usually done through the help of the internet (online) and is aimed at funding a relatively large project. Meanwhile, peer to peer (P2P) lending is a fintech service in Indonesia that brings together both borrowers and lenders who are usually provide fund in small fund and short term.

\section{Aspects of shariah compliance in islamic financial technology}

Rusydiana (2018) defines Islamic fintech as a technology-based business with innovative financial services or products using Islamic or sharia schemes. Like Islamic banking which has purpose to fulfill the needs of Muslim related to economic transaction without violating Islamic law, Islamic fintech has also emerged to accommodate Muslims who want to use this technology-based financial system. The distinguishes that needs to be emphasized is that Islamic fintech is inseparable from the characteristics of Islamic business that rests on the Islamic economic foundation, namely divinity (divine), justice (al-adl), prophethood (an-nubuwah), government (al-khalifah), and results (al-maad) (Alwi, 2018). The ultimate goal of Islamic finance is also to achieve falah by creating maslahah so that the contracts cannot contain elements of usury and gharar, as well as those that can harm others. Some of the contracts implemented by service providers include the Wakalah bil Ujrah contract and the Musharakah contract (Alwi, 2018).

There are two types of Islamic fintech schemes that are well known in Indonesia, namely peer to peer (P2P) and crowdfunding. Islamic 
crowdfunding can be defined as a medium for using a number of funds obtained from a large number of individuals or organizations, to fund projects, business or individual loans, and other needs based on a web -based online platform in accordance with sharia principles (Djawahir, 2018). Crowdfunding with sharia principles has emerged in Singapore in the form of Ethics Pte which has been established since March 2014 (Rasyid, Setyowati, and Islamiyati, 2017). The basic features that characterize Islamic crowdfunding in in Djawahir's (2018) research include only investing in projects or financing activities that are lawful, not using interest, and the existence of a Sharia Supervisory Board or sharia opinion. Meanwhile, the models that can be applied in Islamic crowdfunding include zakat-based, infaq- shadaqah -waqf-based, qard al-hasan based, shirkah -based (such as mudharabah and musharakah), and loan-based (such as murabahah, ijarah, and istishna). These models are expected to be able to maintain Islamic values, because one of the aspects that must be considered in muamalah, including fintech, is the aspect of compliance with Islamic law (sharia compliance).

Sharia compliance is a mechanism to ensure compliance with financial arrangements, contracts and transactions of Islamic financial institutions with sharia principles and rules (AAOIFI, 2018). The sharia compliance system is an on-going process starting from the pre-investment stage and continuing until the post-investment stage (Mannai \& Ahmed, 2018). Therefore, Islamic financial institutions must always comply with or remain within the corridors of sharia principles at any time. In this case, SSB takes an important role to ensure that Islamic financial institutions always maintain their operational activities in line with sharia values. As a guide in implementing sharia compliance monitoring activities, Rosly (2010) recommends at least four parameters that can be used to measure compliance with sharia, namely contract, maqashid sharia, financial reporting, and legal documentation.

First, aqad comes from Arabic, al-aqd which literally means obligation or bond. The validity of the contract lies in the fulfillment of its four principles, 
namely buyers and sellers, prices, goods, offers and acceptance (ijab qabul). While the elements of ambiguity (gharar) should be avoided in Islamic law because their presence will cause defects in the contract and can make it invalid. Therefore, it is necessary to pay attention to what types of contract used in Islamic fintech, whether it meets the principles of sharia or not.

Second, Maqasid sharia has functions for tahsil (safeguarding benefits) and ihqa (avoiding harm or injury). Therefore, this Islamic fintech innovation needs to be tested for legality and must be in accordance with the objectives (maqasid) of sharia. The purpose of this maqashid sharia is to fulfill and protect basic needs in Islamic law, including religion (din), life (nafs), family (nasl), reason ('aql) and property (mal). Maqasid sharia is also expected to be able to ensure that Islamic financial institutions will provide services that can reduce the harm (madarrah) commonly found in Western financing models.

Third, financial reports are intended to provide information about the financial condition, performance and changes in financial position of a company to a variety of users that will be used to make economic decisions. This objective serves to eliminate ambiguity (gharar) and fraud (tatfief) in financial contracts through factual reporting of these transactions. Financial reporting should be understandable, relevant, reliable and comparable as stipulated in the IFRS. In addition, financial reporting for Islamic financial institutions, including in this case of fintech companies, must also meet sharia reporting standards (PSAK Shariah).

Fourth, legal documentation is used to provide security guarantees and protection to the parties involved regarding their rights, obligations and responsibilities which have been clearly stated in the terms of the agreement or contract. If the contract does not work properly, the legal documentation can be used to seek legal protection. Some of the digital economic challenges to the development of the banking business, such as in the security sector (Dz, 2018). Therefore, considering the risks arising from fintech are greater than conventional Islamic financial business models, the legal documentation used 
by Islamic fintech must be stronger. The legal documentation used can be in the form of documents supporting the main contract, such as a guarantee agreement, proof of sale and purchase receipts, an attachment to the profit sharing scheme, and other relevant documents to ensure that the sharia transaction can be executed properly for the parties.

\section{Previous studies}

Previous studies on issues and challenges that will be faced by the Sharia Supervisory Board in the digital era have been conducted by Izzatika and Lubis (2016), Dz (2018), Todorof (2018) and Marzuki (2018). Research from Izzatika and Lubis (2016) describe the challenges of the competence of the Sharia Supervisory Board in Indonesia. Based on the literature study (library research) and the results of the interviews conducted by respondents, there are several challenges related to the competence of the Sharia Supervisory Board in Indonesia. These challenges include upgrading the competence of the Sharia Supervisory Board, collaboration between DSN-MUI and OJK in creating mandatory certification for Sharia Supervisory Board, and educational institutions which capable of meeting industry needs related to the Sharia Supervisory Board.

Furthermore, Dz's research (2018) only focuses on the challenges of digitization for banks. The results of this study state that the many benefits obtained by digitizing Islamic banking services are also in line with the many obstacles and challenges faced in practice. These obstacles and challenges include the presence of high risks and costs, the unavailability of extensive infrastructure, and possibly banking crimes committed by the users themselves.

On the other hand, Marzuki (2018) describes the opportunities and challenges for Indonesian Islamic banks in the era of globalization as research from $\mathrm{Dz}$ (2018). This study recommends a strategy for developing an Islamic banking system that at least needs to pay attention to two fundamental 
aspects, namely the conceptual/academic aspects and the implementation/practical aspects of Islamic banking. The development of the conceptual aspect emphasizes the development of Islamic banking as a science or system, while the development of the implementation aspect emphasizes the development of the Islamic economy which is applied to business institutions that apply sharia principles in running their business (Marzuki, 2018).

Todorof (2018) explains that the chances of international banking world have the opportunity to implement a financial technology based on Islamic principles with business models such as peer to peer lending and crowdfunding to scale cross-border operation indefinitely. This allows potential investors and business people to have investment opportunities and get more varied capital potentials. However, Todorof (2018) also reveales the business risks faced due to the complexity of the business and the increasing openness of markets in cyberspace. On the other hand, Todorof (2018) does not make the issue of sharia as an obstacle in developing the banking market that uses the Islamic fintech approach.

Based on those studies, there is no research that focuses on the issues and challenges faced by the Sharia Supervisory Board related to Islamic fintech innovation. The aspect as well as the anticipatory steps are needed to deal with the increasingly innovative development of Islamic fintech which involving several parties in its contracts.

\section{Methods}

This paper aims to discuss the challenges of sharia supervision in Islamic fintech as well as the formulation of solutions in the form of proposals of regulatory substance and a corporate governance model by optimizing the role of SSB as executing the function of sharia compliance supervision. This paper uses several sources of secondary references obtained from books and scientific journals of national and international that discuss the development 
and the dynamics of financial technology. The law and regulations issued by Bank Indonesia (BI) as well as the Financial Services Authority (OJK), Fatwa of the National Sharia Council (DSN) of the Indonesian Ulema Council (MUI), statistical data, websites of several Islamic fintech's that have operated in Indonesia, and articles discussing the development of Islamic financial technology and the problems faced. Several data sources such as website content on several Islamic fintech's will be analyzed using content analysis to obtain a common thread on the challenges faced by sharia supervision and the governance model currently being implemented. The sample of this study uses a purposive sampling technique with the criteria that Islamic fintech companies have clearly identified their sharia contracts. This is based on the statement of Rosly (2010) that the sharia contract is an important part that can be used as an indicator of the level of sharia compliance.

\section{Result and discussion}

\section{Islamic fintech practices in indonesia}

Islamic fintech in Indonesia is a response to the development of conventional fintech companies that use interest instruments in their operations. Both the Financial Services Authority (OJK) and Bank Indonesia (BI) have played a role in guarding the development of the fintech industry. OJK specifically regulates peer to peer (P2P) lending with OJK Regulation Number 77/POJK.01/2016 concerning Borrowing and Lending Services Based on Information Technology. There are 9 main aspects that are regulated in the regulation, including: (1) fintech registration mechanism, (2) fintech monitoring and surveillance mechanisms; (3) establishment of the fintech ecosystem; (4) building a culture of innovation and collaboration; (5) inclusion and literacy; (6) effective risk management; (7) consumer protection; (8) transparency; and (9) anti-money laundering and terrorism financing. 
On the other hand, Bank Indonesia through Bank Indonesia Regulation (PBI) Number 19/12/PBI/2017 concerning the Implementation of Financial Technology places more emphasis on monitoring and evaluation in developing innovative products, services, technology, and/or financial technology business models. while still paying attention to consumer protection, maintaining the confidentiality of consumer data and/or information, including transaction data and an obligation to use rupiah in every financial transaction. Those aspects are still within the framework of Bank Indonesia's function as guardian of monetary policy and financial stability.

Meanwhile, based on data from the OJK, as of December 20, 2019 there were 164 fintech companies registered and supervised by OJK. The development was followed by the development of Islamic fintech in Indonesia, thus encouraging the establishment of the AFSI (Indonesian Sharia Fintech Association). The idea to establish AFSI started from October 2017 in Jakarta. AFSI is established as a congregation of startups, institutions, academics, communities, and sharia experts engaged in technology-based Islamic financial services. Then, AFSI has been recognized and legalized as a legal entity, through the Decree of the Minister of Law and Human Rights of the Republic of Indonesia Number AHU-0001911.AH.01.07 of 2018 dated 14 February 2018. Based on the information listed on the https://fintechsyariah.id website, several companies running Islamic fintech in Indonesia can be found, including: 
Rifqi Muhammad and Rima Lanaula

Table 1. List of Islamic fintech in Indonesia

\begin{tabular}{cll}
\hline No & \multicolumn{1}{c}{ Companies } & \multicolumn{1}{c}{ Website } \\
\hline 1 & ALAMI Teknologi Sharia & https://www.alamisharia.com \\
2 & Ammana Fintek Syariah & https://ammana.id \\
3 & Digital Market Indonesia & https://alibobostore.com \\
4 & IjabQabul.id & https://ijabqabul.id \\
5 & KSPPS Asy-Syirkah Muamalah Indonesia & https://www.asysyirkahindone \\
& & sia.com \\
7 & Plazadana Mitra Investama & Pttps://plazadana.com \\
8 & PT Alumnia Sinergi Adiperkasa & https://afteroil.id \\
9 & PT Barakah Teknologi Indonesia & https://www.alumnia.id \\
10 & PT Biosphere Lestari Alam & https://wisatamuslim.com \\
11 & PT Dana Syariah Indonesia & https://biosphere.id \\
12 & PT Danakoo Mitra Artha & https://danasyariah.id \\
13 & PT Duha Madani Syariah & https://danakoo.id \\
14 & PT Efunding Teknologi Keuangan & https://duhasyariah.com \\
15 & PT Ethis Fintek Indonesia & https://efunding.id \\
16 & PT Kandang Karya Teknologi & https://ethis.co.id \\
17 & PT Kapital Boost Indonesia & https://kandang.in \\
18 & PT Kerjasama Untuk Negeri & https://kapitalboost.co.id \\
19 & PT Maslahat Indonesia Mandiri & https://kerjasama.com \\
20 & PT Muslim Indonesia Barokah & https://bsalam.id \\
21 & PT Naqif Solusi Indonesia & http://muslimnesia.co.id \\
22 & PT Privy Identitas Digital & https://oneshaf.com \\
23 & PT Qazwa Mitra Hasanah & PTttps://privy.id \\
24 & PT Rachmad Dharma Anugrah & https://qazwa.id \\
25 & PT Solusi Umroh Indoteknoasia & https://moneyz.id \\
& https://umrohnesia.co.id \\
& & \\
& & https://urunmodal.id \\
& &
\end{tabular}




\begin{tabular}{lll}
\hline No & \multicolumn{1}{c}{ Companies } & \multicolumn{1}{c}{ Website } \\
\hline 28 & PT Yuk Hijra Bersama & https://hijra.co.id \\
29 & PT Zahir Internasional & https://zahiraccounting.com \\
30 & PT. Agro Wira Yasa & https://igrowchain.com \\
31 & PT. Berbagi Resiko Universal & https://birurisk.com \\
32 & PT. Berkah Finteck Syariah & https://finteksyariah.co.id \\
33 & PT. Berkah Inovasi Nusantara & https://invesproperti.id \\
34 & PT. Bersatu Kuat Kapital & https://kongsian.id \\
35 & PT. Digital Muslim Global & https://muslimapp.id \\
36 & PT. Halalvestor Global Asia & https://halalvestor.com \\
37 & PT Jual Beli Kredit Indonesia & https://jualbelikredit.id \\
38 & PT Mobilima Syariah Internasional & https://mobilima.com \\
39 & PT Provesty Global Nusantara & https://provesty.com \\
40 & PT. Saqofa Digital Mulia & https://mudahumroh.com \\
41 & PT Sinergi Inti Berkah Investama & https://goolive.id \\
42 & PT. Syarfi Teknologi Finansial & https://www.syarfi.id \\
43 & PT Teknologi Berdikari Indonesia & https://angsur.id \\
44 & PT Tong Dun Technology Indonesia & https://tongdun.net \\
45 & Tamasia Global Sharia & http://tamasia.co.id \\
46 & Xedeka Derma Khatulistiwa & https://xedeka.com \\
\hline & &
\end{tabular}

Source: compiled by the author (2019) and Indonesian Sharia Fintech Association

Based on that data, the authors use a purposive sampling technique by determining the criteria for Islamic fintech companies to be analyzed, namely Islamic fintech companies whose sharia contracts can be identified clearly, for example using murabahah, mudharabah or musharakah contracts. Based on these criteria, it turns out that only 18 Islamic fintech companies in Indonesia have clearly identifiable sharia contracts.

Economica: Jurnal Ekonomi Islam - Volume 10, Nomor 2 (2019) 
Rifqi Muhammad and Rima Lanaula

Table 2. List of Islamic fintech in Indonesia (which the contracts can be identified)

\begin{tabular}{|c|c|c|c|c|c|}
\hline No & Companies & $\begin{array}{l}\text { Registered } \\
\text { in } 0 \mathrm{JK}\end{array}$ & SSB & Product & Aqad \\
\hline 1 & $\begin{array}{l}\text { ALAMI Teknologi } \\
\text { Sharia }\end{array}$ & Yes & Yes & $\mathrm{P} 2 \mathrm{P}$ & $\begin{array}{l}\text { Wakalah dan } \\
\text { Qardh }\end{array}$ \\
\hline 2 & $\begin{array}{l}\text { Ammana Fintek } \\
\text { Syariah }\end{array}$ & Yes & Yes & $\mathrm{P} 2 \mathrm{P}$ & Mudharabah \\
\hline 3 & IjabQabul.id & No & No & Ecommerce & $\begin{array}{l}\text { Mudharabah, } \\
\text { Ijarah, } \\
\text { Murabahah }\end{array}$ \\
\hline 4 & $\begin{array}{l}\text { KSPPS Asy-Syirkah } \\
\text { Muamalah } \\
\text { Indonesia }\end{array}$ & No & Yes & Crowdfunding & $\begin{array}{l}\text { Mudharabah } \\
\text { dan Musyarakah }\end{array}$ \\
\hline 5 & $\begin{array}{l}\text { Plazadana Mitra } \\
\text { Investama }\end{array}$ & No & No & Crowdfunding & $\begin{array}{l}\text { Musyarakah dan } \\
\text { Wakalah }\end{array}$ \\
\hline 6 & $\begin{array}{l}\text { PT Afteroil Energi } \\
\text { Utama }\end{array}$ & No & No & Crowdfunding & Syirkah \\
\hline 7 & $\begin{array}{l}\text { PT Dana Syariah } \\
\text { Indonesia }\end{array}$ & Yes & Yes & $\mathrm{P} 2 \mathrm{P}$ & Murabahah \\
\hline 8 & $\begin{array}{l}\text { PT Danakoo Mitra } \\
\text { Artha }\end{array}$ & Yes & Yes & $\mathrm{P} 2 \mathrm{P}$ & Mudharabah \\
\hline 9 & $\begin{array}{l}\text { PT Duha Madani } \\
\text { Syariah }\end{array}$ & Yes & Yes & $\mathrm{P} 2 \mathrm{P}$ & $\begin{array}{l}\text { Wakalah, Waad, } \\
\text { Murabahah, } \\
\text { Ijarah }\end{array}$ \\
\hline 10 & $\begin{array}{l}\text { PT Ethis Fintek } \\
\text { Indonesia }\end{array}$ & Yes & Yes & $\mathrm{P} 2 \mathrm{P}$ & $\begin{array}{l}\text { Musyarakah dan } \\
\text { Wakalah }\end{array}$ \\
\hline 11 & $\begin{array}{l}\text { PT Kandang Karya } \\
\text { Teknologi }\end{array}$ & No & No & Crowdfunding & Mudharabah \\
\hline 12 & $\begin{array}{l}\text { PT Kapital Boost } \\
\text { Indonesia }\end{array}$ & Yes & Yes & $\mathrm{P} 2 \mathrm{P}$ & Murabahah \\
\hline 13 & $\begin{array}{l}\text { PT Maslahat } \\
\text { Indonesia Mandiri }\end{array}$ & Yes & Yes & $\mathrm{P} 2 \mathrm{P}$ & Musyarakah \\
\hline 14 & $\begin{array}{l}\text { PT Qazwa Mitra } \\
\text { Hasanah }\end{array}$ & Yes & Yes & $\mathrm{P} 2 \mathrm{P}$ & $\begin{array}{l}\text { Mudharabah } \\
\text { dan Murabahah }\end{array}$ \\
\hline 15 & $\begin{array}{l}\text { PT. Berkah Finteck } \\
\text { Syariah }\end{array}$ & Yes & Yes & $\mathrm{P} 2 \mathrm{P}$ & $\begin{array}{l}\text { Mudharabah } \\
\text { dan Musyarakah }\end{array}$ \\
\hline 16 & $\begin{array}{l}\text { PT Mobilima } \\
\text { Syariah } \\
\text { Internasional }\end{array}$ & No & Yes & $\mathrm{P} 2 \mathrm{P}$ & Murabahah \\
\hline 17 & $\begin{array}{l}\text { PT Provesty } \\
\text { Global Nusantara }\end{array}$ & No & No & Crowdfunding & $\begin{array}{l}\text { Murabahah dan } \\
\text { Musyarakah } \\
\text { Mutanaqisah }\end{array}$ \\
\hline 18 & $\begin{array}{l}\text { PT Teknologi } \\
\text { Berdikari } \\
\text { Indonesia }\end{array}$ & No & No & Installment & Murabahah \\
\hline
\end{tabular}

Source: compiled by the author (2019) 
Table 2 shows that there are some interesting findings to be discussed such as: First, there are only 12 companies from 18 companies that have Sharia Supervisory Board or Sharia Advisor. Furthermore, from those 12 Islamic fintech companies that have SSB, only 10 companies which are registered in OJK (data for December 20, 2019). Those 10 companies provide more information than others that are not supervised by OJK and SSB. One example is the clarity of the product offered and the types of the contract carried out. This proves the important role of the Sharia Supervisory Board in supervising Islamic fintech. The existence of SSB in sharia fintech companies can affect the credibility and public trust in the company. Based on the data above, it can be concluded that the problems related to Islamic fintech include the lack of supervision on sharia compliance, the lack of information presented, and the absence of financial reports that can be accessed by the public.

Second, the contracts used by Islamic fintech companies are also quite diverse. However, there are two contracts that are usually used in accordance with the business model used by the Islamic fintech company, namely murabaha and mudharaba contracts. Murabaha is usually used in peer to peer lending business model where the position of the Islamic fintech company as a platform provider as well as a seller of products provided by certain vendors/suppliers. The investors in this contract is only the provider of funds with a wakalah or mudharaba muqayyadah contract, and they do not make a direct contract with the recipient of the financing. However, investors can also enter into a contract directly with the recipient of the financing with the mudharabah contract. Islamic fintech companies in these conditions will take a fee for providing platform services in the certain percentage or nominal amount as part of a provision in the financial technology platform.

Third, financial reports of all Islamic fintech companies cannot be found. It is became a particularly concerning note, considering that financial information is important in the practice of the Islamic financial industry. 
Prospective customers, investors, and recipients of financing need adequate information about the ability of Islamic fintech companies to manage their finances properly and credibly. Ethiscrowd is probably the only Islamic fintech company that has started preparing reports, even though it does not provide financial reports, but in the form of Social Responsibility Report. The report prepared by Ethiscrowd is a form of social responsibility that reveals the social impacts that have been generated from the practice of Islamic fintech. Meanwhile, Kapitalboost strives to innovate products that are not only commercial in nature, but also products of a social nature, for example helping to finance medical expenses with the qardh contract.

\section{Roles and challenges to be faced by the sharia supervisory board}

The Accounting and Auditing Organization for Islamic Financial Institutions (AAOIFI) is an international non-profit institution that provides accounting and auditing standards for Islamic financial institutions in the world. AAOIFI requires a Sharia Supervisory Board (SSB) as a component in the governance of Islamic financial institutions. The existence of SSB in the activities of Islamic financial institutions is very important in assessing the implementation of sharia principles, such as analyzing Islamic banking operations and assessing bank activities and products (Djumardin and Isnaini 2018). In addition, SSB also uses supervision or controlling methods to ensure that Islamic financial institutions have orientation on the maqashid of sharia. Supervision in language means riqabah (guarding, administering and monitoring), as Allah says in Surah An-Nisa verse 1: "Surely, Allah is ever watchful over you". Supervision in the term of sharia means monitoring (isyraf), examination (muraja'ah) and investigation (fahsh) aimed at safeguarding benefits (mura'at maslahah) and avoiding destruction (idra 'mafsadah).

SSB has role to supervise and control the internal aspect of Islamic financial institutions. Optimizing the role of SSB is very important to ensure 
that every transaction conforms to sharia principles that refer to the Quran and Sunnah, in this case is the fatwa of the National Sharia Council (DSN) of the Indonesian Ulema Council (MUI) (Prabowo and Jamal 2017). SSB is representative of the DSN-MUI who received the mandate to conduct monitoring in the operational activities of Islamic financial institution and also as part of the organ of DSN-MUI placed in their respective Islamic financial institutions. Therefore, SSB needs to refer to the Fatwa of the DSN-MUI, especially in the supervision process in sharia financial institutions that are within the scope of law in Indonesia. SSB has also contribution to create credibility for Islamic financial institutions (Mannai and Ahmed 2018). If SSB does not play an optimal role in sharia compliance practices, it will influence the image and credibility of Islamic financial institutions. Then this can affect the assessments of the community and reduce the public confidence to the Islamic financial institutions.

Apart from supervising the operational activities of Islamic financial institutions, SSB also has a bigger role to help encouraging the development of the economics and Islamic finance in Indonesia, one of which is the innovation of Islamic fintech products. Financial product and service innovations need to be supported by a governance structure that is able to accelerate the development of customer needs and financial markets (Apriyanti, 2018). Apriyanti (2018) proposes.

Working Group at the national level that is able to seize opportunities, ideas and needs for innovating Islamic financial products and services, especially Islamic banking.

On the other hand, Rusydiana (2018) and Rasyid et al. (2017) state that SSB is one of the actors that should be involved in the development of Islamic fintech in Indonesia. Moreover, DSN-MUI has also issued fatwa No 117/DSNMUI/II/2018 concerning Information Technology-Based Financing Services based on Sharia Principles (DSN-MUI, 2018). Several things that are important in this fatwa include: First, this technology-based financing service does not 
conflict with sharia principles, namely avoiding the elements of usury, gharar, maysir, tadlis, dharar, zhulm, and haram. Second, providing sharia contracts that are in line with financing institutions (for example: murabaha, mudharaba, ijarah, qardh, and wakala) and fulfill the principles of balance, justice and fairness in accordance with sharia and applicable laws and regulations. Third, using financing models such as factoring financing; financing for procurement of third party orders (purchase order); financing for procurement of goods for business actors who sell online (online seller); financing for procurement of goods for business actors who selling online with payment gateway operators; funding for employees; and community-based financing.

SSB is also part of the governance instrument in Islamic financial institutions with sharia governance approach which has been established in Malaysia (Hasan 2011). Corporate governance is formulated by the Organization for Economic Co-operation and Development (OECD). Sudi (2016) defines corporate governance as "the full relationship between company management, the supervisory board, shareholders, and related parties". Corporate governance is also a system for directing and monitoring company goals. Sudi (2016) add that investors consider the independence of supervisors as an important aspect of corporate governance. Therefore, SSB is part of corporate governance which ensures that Islamic financial institutions operate within the corridors of the objectives of Islamic financial institutions to achieve falah and maslahah.

Some of the challenges that may be faced in the development of Islamic fintech include the lack of policy instruments that maintain the fintech working process, the availability of adequate human resources, and high security risks from malware attacks (Rusydiana, 2018). Especially, the lack of regulations about Islamic fintech certainly has the potential to inhibit the development of Islamic fintech. There is only general regulation for fintech and not Islamic fintech. Therefore, regulator can use Fatwa DSN No. 117/DSN- 
MUI/II/2018 concerning Information Technology-Based Financing Services based on Sharia Principles as a reference in drafting regulations in the field of Islamic fintech in Indonesia so that it is in line with the spirit of DSN in realizing financial practices according to Islamic values.

Furthermore, with regard to human resources (in this case is SSB), some studies such as Izzatika and Lubis (2016) and Prabowo and Jamal (2017) reveal that SSB in Indonesia is still less adequate for competence because the expertise of SSB is expected not only sharia knowledge but also technical knowledge about operations of sharia banking and finance. Izzatika and Lubis (2016) find that there are at least three issues or problems related to the SSB in Indonesia, among others are: first, the imbalance of competencies possessed by SSB between finance and accounting knowledge and sharia knowledge. Second, the certification agency for SSB members has not functioned optimally. Third, the lack of educational and training institutions that provide sharia accounting and/or auditing so that the existing SSB is still limited in competence.

Prabowo and Jamal (2017) state that in Indonesia, the majority of SSB are selected from religious leaders although they have lack of expertise in auditing, economics, accounting and business law. This certainly affects the quality of the supervision carried out because technically, sharia supervision uses the basics of auditing techniques learned in the field of accounting, even though the substance being examined is related to sharia issues. On the other hand, innovations in the field of Islamic finance are increasingly being implemented in the banking industry and other Islamic financial institutions, this certainly makes SSB is expected to keep following the practical developments by updating their insights through seminars, workshops and Ijtima 'Sanawi which are regularly held by DSN-MUI for SSB members.

Therefore, SSB members will face bigger challenges to always update their knowledge in certain aspects such as sharia financial business practices, technical supervision, business law, and DSN-MUI fatwas. In connection with 
the development of Islamic fintech practices, this industry is becoming increasingly complex because the practitioners in this field continue to innovate along with developments in technology and business models using the concept of sharia. For example, the development of the Islamic crowdfunding business model that seeks to develop community participation in a project both for profit and non-profit (social finance). This business models will use technological sophistication that is in line with the rules of Sharia to be free from elements of maysir, gharar, usury (Rasyid, et. al., 2017). The role of SSB is needed to ensure that this mechanism works properly. This means that SSB must also understand whether the mechanism that is implemented with the help of modern technology is truly free from maysir, gharar and usury.

\section{Conclusion}

The development of the Islamic financial industry in Indonesia is motivated by the awareness of the Muslim community of the incompatibility of conventional financial institutions with Islamic values. In order to continue to gain the trust of the public, Islamic financial institutions are expected to adhere to Islamic principles in their activities. Apart from maintaining Islamic principles to gain market share, Islamic banks must always make innovations related to their products and services. The demand for innovation is very important and urgent in the era of globalization, especially since the emergence of financial technology (fintech). The emergence of modern financial businesses such as fintech is a challenge for Islamic financial institutions as well as a challenge for the sharia supervisory board which is responsible for monitoring the sharia compliance of these institutions. The paper emphasizes the importance of SSB's existence in the Islamic fintech business because of the possibility of dynamic developments and increasingly complex product and service innovations. 
Based on the fact of the practice carried out by several Islamic fintech in Indonesia that are members of the Indonesian Sharia Fintech Association (AFSI), there are several important notes that become challenges for SSB in sharia supervision: first, the regulations in Indonesia (both issued by BI and OJK) has not been able to reach Islamic fintech practices even though DSN-MUI already has a regulatory concept as reflected in Fatwa Number 117/DSNMUI/II/2018 concerning Information Technology-based Financing Services based on Sharia Principles.

Second, as a consequence of the absence of regulations related to Islamic fintech, the existence of DPS in each Islamic fintech company is still voluntary. Third, the contracts used in Islamic fintech companies also do not have uniformity with one another and tend to be very independent. There are even some companies that do not have operational permits from the OJK. This certainly has an impact on the reputation of the Islamic fintech industry in general and endangers the parties associated with the industry.

Fourth, seeing the complexity of the Islamic fintech business will certainly bring challenges to regulators in sharia supervision to protects customers associated with Islamic fintech companies because their physical existence is sometimes not well validated. Finally, before this industry gets bigger and more complex, it is necessary to formulate a mechanism to regulate and control its operational activities to protect the parties who have entered the Islamic fintech business circle. The practice of Islamic fintech (for example Islamic crowdfunding) must use a mechanism that is in accordance with Islamic rules and laws to be free from elements of maysir, gharar, and usury (Rasyid, et. al., 2017). This mechanism is intended to measure the performance of Islamic fintech practices accordance to meet the parameters of sharia compliance, namely contracts, maqashid sharia, financial reporting, and legal documentation. 
The instrument of organizational governance with sharia principles that is responsible for sharia compliance of a sharia financial institution is SSB. The board is responsible for sharia compliance and has responsibility for the process of developing products and services within the framework of sharia compliance. Therefore, optimizing the functions and roles of SSB is very important, especially regarding to the qualifications and competences of the members. The selection of SSB members is not only look from the competence of religion (the science of jurisprudence of muamalah), but also consider other related knowledge such as business studies, economics, accounting, as well as their understanding of information technology.

\section{Recommendations for ssb in the islamic fintech industry}

Based on issues and challenges in the future, especially related to the development of Islamic fintech, SSB is expected to be more optimal in carrying out its duties and responsibilities with a recruitment process with special qualifications so that it is in line with the character of Islamic fintech companies (Prabowo and Jamal 2017). These qualifications as conveyed by Faozan (2014) in his research are the science of fiqh muamalah, operational of financial institutions, supervisory functions and mastering in general administration.

In addition, the authors recommend that SSB in Islamic fintech companies also have sufficient competence in the field of financial engineering and information technology so that they are able to detect the possibility of financial fraud caused by weak information technology security systems both from within the company and from outside the company. SSB is also required to always improve its competence with a commitment to attend trainings and seminars related to developments in the field of Islamic finance and information technology (Faozan, 2014).

Another thing that regulators need to immediately formulate in collaboration with OJK and Bank Indonesia is the holding of a certification 
exam for the SSB profession by determining the competencies that are expected to be mastered. This professional competence needs to be legalized by the National Professional Certification Agency (BNSP) as has been initiated by the DSN Institute by establishing a Sharia Supervisory Competency Certification Scheme. Several competencies that have been formulated include: (a) inventory of sharia supervision materials in accordance with their duties; (b) supervision of the agreement deed; (c) supervision of new product and/or service procedures; (d) supervision of product marketing; (e) supervision of financial reports; and (f) formulating a sharia opinion.

This initial step needs to be considered although there are still many competencies that need to be mastered by prospective sharia supervisors, especially in Islamic fintech companies which having business complexity as well as product and service innovations that can penetrate space and time boundaries. The form of innovation in Islamic fintech companies does not only involve commercial business models or social activity models, but also combines social and commercial activities in one scheme to provide a broad socio-economic impact on society.

\section{References}

AAOIFI. (2018). Exposure Draft (Ver. 4.0) of Governance Standard No. 9 Shariah Compliance Function. In Governance Standard for Islamic Financial Institutions. Manama: AAOIFI.

Alwi, A. B. (2018). Pembiayaan Berbasis Teknologi Informasi (Fintech) Yang Berdasarkan Syariah. Al-Qanun, 21(2), 255-71.

Apriyanti, H. W. (2018). Model Inovasi Produk Perbankan Syariah Di Indonesia. Economica: Jurnal Ekonomi Islam 9 (1): 83-104. https://doi.org/https://dx.doi.org/10.21580/economica.2018.9.1.205.

Asosiasi Fintech Syariah Indonesia. (2020). Member AFSI. Accessed January 11, 2020. https://fintechsyariah.id/id/members. 
Bank Indonesia. (2017). Peraturan Bank Indonesia (PBI) Nomor 19/12/PBI/2017 tentang Penyelenggaraan Teknologi Finansial. Jakarta: Bank Indonesia

Bank Indonesia. (2019). Teknologi Finansial. Accessed February 1, 2019. https://www.bi.go.id/id/sistempembayaran/fintech/Contents/default.aspx.

Dewan Gubernur BI. (2017). Peraturan Anggota Dewan Gubernur Nomor 19/15/PADG/2017 Tentang Tata Cara Pendaftaran, Penyampaian Informasi, Dan Pemantauan Penyelenggara Teknologi Finansial. Jakarta: Bank Indonesia.

Dewan Syariah Nasional MUI. (2018). Fatwa Dewan Syariah Nasional-Majelis Ulama Indonesia Tentang Layanan Pembiayaan Berbasis Teknologi Informasi Berdasarkan Prinsip Syariah. Jakarta: DSN-MUI.

Djawahir, A. U. (2018). Teknologi-Layanan Keuangan, Literasi-Inklusi Keuangan, Dan Value Pada Fintech Syariah Di Indonesia: Perspektif S-OR (Stimulus-Organism-Response) Model. In 2nd Proceedings Annual Conference for Muslim Scholars, 439-48. Surabaya.

Djumardin \& Atin M. I. (2018). The Existence of Sharia Supervisory Board in Maintaining the Purpose of Sharia Principles in Sharia Banking. Journal of Legal, Ethical and Regulatory, Issue 21 (3), 1-6.

Dz, A. S. (2018). Inklusi Keuangan Perbankan Syariah Berbasis DigitalBanking: Optimalisasi Dan Tantangan. Al-Amwal, 10 (1): 63-80. https://doi.org/10.24235/amwal.v10i1.2813.

Faozan, A. (2014). Optimalisasi Peran Dewan Pengawas Syariah Pada Lembaga Keuangan Syariah. El-Jizya, 2 (1).

Hadad, M. D. (2017). Financial Technology (FinTech) Di Indonesia. Jakarta: Otoritas Jasa Keuangan.

Hasan, Z. (2011). A Survey on Shari'ah Governance Practices in Malaysia, GCC Countries and the UK: Critical Appraisal. International Journal of Islamic and Middle Eastern Finance and Management, 4 (1), 30-51. https://doi.org/10.1108/17538391111122195.

Izzatika, Nadia F., \& Lubis, A. T. (2016). Isu Dan Tantangan Kompetensi Dewan Pengawas Syariah Di Indonesia. Jurnal Akuntansi Dan Keuangan Islam, 4 (2), 147-167. 
Mannai, M. A. \& Ahmed, H. (2018). Exploring the Workings of Shari'ah Supervisory Board in Islamic Finance: A Perspective of Shari'ah Scholars from GCC. The Quarterly Review of Economics and Finance. https://doi.org/10.1016/j.qref.2018.05.017.

Marsudi, A. S. \& Widjaja, Y. (2019). Industri 4.0 Dan Dampaknya Terhadap Financial Technology Serta Kesiapan Tenaga Kerja Di Indonesia. Ikraith Ekonomika, 2 (2): 1-10.

Marzuki, S. N. (2018). Bank Syariah Di Indonesia (Peluang Dan Tantangan Di Era Globalisasi). Jurnal Ekonomi Syariah, I (1), 79-90.

Otoritas Jasa Keuangan. (2016). Peraturan Otoritas Jasa Keuangan Nomor 77/POJK.01/2016 Tentang Layanan Pinjam Meminjam Uang Berbasis Teknologi Informasi. Jakarta: OJK. . (2018). Peraturan Otoritas Jasa Keuangan Nomor 13/POJK.02/2018 Tentang Inovasi Keuangan Digital di Sektor Jasa Keuangan. Jakarta: OJK.

___. 2019a. Perkembangan Fintech Lending (Pendanaan Gotong Royong Online). Jakarta. https://www.ojk.go.id/id/kanal/iknb/data-danstatistik/fintech/Pages/Statistik-Fintech-Lending-Periode-November2019.aspx.

- - 2019b. Perusahaan Fintech Lending Berizin Dan Terdaftar Di OJK per 20 Desember 2019. Jakarta: OJK.

Prabowo, B. A. \& Jasri Bin Jamal. (2017). Peranan Dewan Pengawas Syariah Terhadap Praktik Kepatuhan Syariah Dalam Perbankan Syariah Di Indonesia. Jurnal Hukum IUS QUIA IUSTUM, 24 (1), 113-129.

Rasyid, M. A., Setyowati, R., and Islamiyati. (2017). Crowdfunding Syariah Untuk Pengembangan Produk Perbankan Syariah Dari Perspektif Shariah Compliance. Diponegoro Law Journal, 6 (4), 1-16. https://ejournal3.undip.ac.id/index.php/dlr/\%0Apencegahan.

Rosly, S. A. (2010). Shariah Compliant Parameters Reconsidered. International Journal of Islamic Middle Eastern Fiannce and Management, 3(2), 132146.

Rusydiana, A. S. (2018). Developing Islamic Financial Technology In Indonesia. Hasanuddin Economics and Business Review, 2 (2), 143-152. https://doi.org/10.26487/hebr.v. 
Rifqi Muhammad and Rima Lanaula

Sudi, D. M. (2016). Efektivitas Dewan Pengawas Syariah Pada Perbankan Syariah. 1st ed. Yogyakarta: Deepublish.

Todorof, M. (2018). Shariah-Compliant FinTech in The Banking Industry. ERA Forum, 19(1), 1-17. https://doi.org/10.1007/s12027-018-0505-8.

Undang-Undang Nomor 40 Tahun 2007 Tentang Perseroan Terbatas (Limited Company). 